Journal of Agrometeorology 23 (3) : 316-323 (September 2021)

\title{
Trend and change point detection of seasonal rainfall for effective crop planning over southern transition zone of Karnataka, India**
}

\section{S. SRIDHARA* and PRADEEP GOPAKKALI}

\author{
Centre for Climate Resilient Agriculture \\ University of Agricultural and Horticultural Sciences, Shivamogga, Karnataka, India \\ Corresponding Author: sridharas1968@gmail.com
}

\begin{abstract}
The significance of the trends was tested by Mann-Kendall test for annual and seasonal rainfall. Among the 14 taluks, only Hassan taluk shows a significant positive trend in annual rainfall while eight taluks have shown non-significant positive trend and remaining five taluks have shown non-significant negative trend. The annual rainfall for the entire zone have shown non-significant positive trend. For the SWM season, Alur taluk shows a significant negative trend and eight taluks have shown non-significant positive trend. However, five taluks and whole zone showed a non-significant negative trend. Southwest monsoon and annual rainfall in Bhadravathi taluk was increased in $2007(571.9 \mathrm{~mm}$ to $785.1 \mathrm{~mm}$ and $857.6 \mathrm{~mm}$ to 1090.9 $\mathrm{mm}$, respectively) and in Shivamogga, the change in annual rainfall was decreased during 1983 (1497.5 mm to $944.0 \mathrm{~mm}$ ) and $2011(944.0 \mathrm{~mm}$ to $796.6 \mathrm{~mm}$ ). The northeast monsoon rainfall was increased during 1992 (134.3 $\mathrm{mm}$ to $441.1 \mathrm{~mm})$ and it was decreased during $1994(441.1 \mathrm{~mm}$ to $162.0 \mathrm{~mm})$ in Shikaripura taluk. Similarly, in Hunsur taluk, the SW Monsoon rainfall has increased $(701.8 \mathrm{~mm}$ to $1010.2 \mathrm{~mm}$ ) during 1991 and it was decreased during 2001 (1010.2 mm to $723.3 \mathrm{~mm}$ ), in Periyapatna and Honnali taluk, Northeast monsoon rainfall has decreased during 2012 and 2011, respectively.
\end{abstract}

Key words: Change point detection, Mann- Kendall test, rainfall, trend

Climate change becomes a threat and it affects mainly on rainfall and temperature in various parts of the globe and seeks much attention to it (Yang et al., 2012). Water resource management is directly and indirectly affected by every change in precipitation interns; it alters the fresh water accessibility and their by food security (Hu et al., 2017). Many studies conducted across the globe have shown variations in rainfall patterns over time (Altava-Ortiz et al., 2011). Any change in precipitation has an effect on water resource management, fresh water accessibility and food production as well as nutritional security, both directly and indirectly (Hu et al., 2017). Global climate change has an effect on long-term rainfall patterns, which affects water supply and raises the risk of extreme drought and flooding. The instantaneous heavy rainfall during the monsoon season (June-August) will result in a water shortage during the non-monsoon season. Large storage structures are needed to manage the natural flow according to the region due to the variability of rainfall in terms of distribution and mismatch between water demand and accessibility (Kundu et al., 2015).
On various spatial scales, trend analysis of rainfall, temperature and other climatic parameters can aid in the development of possible climate scenarios (Lunagaria et al.,2012).

Various researchers prefer the Mann-Kendall test (Mann, 1945 and Kendall, 1975) as one of the best methods. The Mann-Kendall test is used for analysis and the hypothesis test of hydrological variables defines statistical significance (Yue and Hashin, 2003). Mann Kendall test as well explains the slope's function in the trend, type of probability distribution and coefficient of variation (Yue et al., 2002). Since, the test excludes the serial dependency effect on auto-correlated data, which alters the variance in data sets; thus, it is used as a tool for trend analysis (Hamed and Rao, 1998). Sen's nonparametric slope estimation approach determines the magnitude of a trend (Sen, 1968) and the trend line in the time series is assumed to be a linear function in this system.

For decades, researchers in statistics and data

** Paper presented in National Seminar “AGMET 2020” held at KAU, Thrissur during 20-22 January 2020. 
mining communities have been interested in detecting fluctuations in time-series data (Basseville and Nikiforov, 1993). The change-point analysis is emerged as a commanding new means for assessing the change occurrence and for detecting slight changes missed by control charts. Furthermore, it provides confidence levels and intervals to better explain the changes observed. A change-point analysis is not a substitute for control charting when collecting online data. However, since a change-point analysis can offer additional information, these two approaches can be used in tandem. Changepoint analysis is desirable to control charting while analyzing historical data, particularly while dealing with large data sets. This method is more efficient with better characterization of changes and also manages the overall error rate. It is also easier to use, robust to outliers and found more versatile.

Control charts have traditionally been used to detect changes. Change-point analysis differs from control charting in terms that, control charts can be updated after each data point is collected, while changepoint analysis can only be done after all the data has been collected. Control charts are superior at identifying isolated abnormal points and detecting major changes rapidly, while change-point analysis can detect subtle changes that control charts frequently miss. These two approaches may be used in conjunction for the analysis (Patakamuri et al., 2020). A change-point analysis has the benefit of controlling change-wise error rate. Thus, each change identified is may be factual and the point-wise error rate will be shown in control charts.

When there are thousands of data points, even in the absence of change, a large number of them will surpass the control limits. Thus, change-point analysis offers many advantages over others. In view of above, this study has attempted to examine seasonal as well as annual rainfall trends and shifts in order to better understand the recent changes in rainfall patterns in the region.

\section{MATERIALS AND METHODS}

\section{Site description and data collection}

The Southern transition zone covers 14 taluks

of 5 districts, spread over Mysuru, Shivamogga, Hassan, Davanagere and Chikkmagalore districts, is a narrow strip of land stretching from Shikaripura taluk of Shivamogga district in the north to Heggada Devana Kote (H. D. Kote) taluk of Mysuru district in the south. It extends from $12^{\circ} 05^{\prime} 16.67^{\prime \prime} \mathrm{N}$ to $14^{\circ} 16^{\prime} 04.16^{\prime \prime} \mathrm{N}$ latitude and $75^{\circ} 21^{\prime} 21.34^{\prime \prime} \mathrm{E}$ to $76^{\circ} 19^{\prime} 54.80^{\prime \prime} \mathrm{E}$ longitudes. The zone is sandwiched between hilly zone in the west and dry zone in the east. Geographical area of 13.1 lakh hectare is covered under the zone, which is 6.88 per cent of the state geographical area.

Daily rainfall data were collected from Karnataka State Natural Disaster Monitoring Centre (KSNDMC) Bengaluru for rain gauge stations working under their control. To work out a reasonable balance between lengths of data, the number of stations, and making it up to the most recent, the data period 1980-2018 was considered for analysis. The software Weathercock 15 developed by CRIDA, Hyderabad was used for computing different characteristics of rainfall.

\section{Mann - Kendall (M-K) test for trend analysis}

Non-parametric test given by Mann, 1945 and Mckee et al., 1993 has been extensively employed to determine the importance of monotonic trend in meteorological time series.

\section{Change point detection}

In historical climate data series, the change point detection method is an excellent means for detecting climatic eroticism. Recognizing a change point in a climate series is critical as this affects the hydrological cycle processes. Cumulative sum charts (CUSUM) and bootstrapping can be used together to identify changes over several iterations. The change point analyzer is a Microsoft Excel add-in program that detects change points in a dataset (Taylor, 2000). Using MSE and CUSUM maps, this analyzer is a valuable method for determining the exact year when a transition or shift occurs. The confidence levels and level of change reflect the massive change point in the entire dataset. If the data series does not shift, the values will usually oscillate between the horizontal axis. The building of the CUSUM chart is the first step in the analysis. CUSUM charts are made for data by computing and plotting a cumulative sum. Let, $\mathrm{X} 1, \mathrm{X} 2 \ldots, \mathrm{X}_{14}$ represent the 14 data points. From this, the cumulative sums S0, S1..., S14 are calculated. The cumulative sums are computed as follows: 
Table 1: Seasonal statistics of rainfall for different taluks of the southern transition zone

\begin{tabular}{lrrrrrrrrr}
\hline \multirow{2}{*}{ Taluks } & \multicolumn{3}{c}{ Annual } & \multicolumn{4}{c}{ Southwest Monsoon } & \multicolumn{3}{c}{ Northeast Monsoon } \\
\cline { 2 - 10 } & Mean & \multicolumn{1}{c}{ SD } & CV & Mean & SD & CV & Mean & SD & CV \\
\hline Tarikere & 910.7 & 196.9 & 21.6 & 586.4 & 147.5 & 25.2 & 198.9 & 112.9 & 56.8 \\
Channagiri & 788.1 & 193.0 & 24.5 & 480.9 & 140.5 & 29.2 & 184.4 & 111.3 & 60.3 \\
Honnali & 662.1 & 215.6 & 32.6 & 384.1 & 131.5 & 34.2 & 171.7 & 114.7 & 66.8 \\
Alur & 1592.3 & 418.3 & 26.3 & 1159.0 & 351.2 & 30.3 & 234.8 & 122.9 & 52.3 \\
Arkalgudu & 899.3 & 223.2 & 24.8 & 550.9 & 151.7 & 27.5 & 193.5 & 96.2 & 49.7 \\
Belur & 1274.1 & 307.1 & 24.1 & 865.4 & 227.7 & 26.3 & 212.9 & 118.6 & 55.7 \\
Hassan & 744.7 & 186.5 & 25.0 & 406.4 & 118.8 & 29.2 & 173.3 & 88.2 & 50.9 \\
Holenarsipura & 737.1 & 206.2 & 28.0 & 362.7 & 127.5 & 35.2 & 205.5 & 121.2 & 59.0 \\
H.D.Kote & 858.9 & 195.7 & 22.8 & 641.6 & 219.2 & 34.2 & 193.7 & 102.4 & 52.9 \\
Hunsur & 790.8 & 218.7 & 27.7 & 392.3 & 129.7 & 33.1 & 207.2 & 147.4 & 71.1 \\
Periyapatna & 870.3 & 167.4 & 19.2 & 453.2 & 128.8 & 28.4 & 206.6 & 95.9 & 46.4 \\
Bhadravathi & 929.4 & 238.2 & 25.6 & 637.5 & 191.9 & 30.1 & 176.8 & 103.2 & 58.4 \\
Shikaripura & 968.0 & 230.0 & 23.8 & 683.6 & 185.8 & 27.2 & 167.8 & 95.1 & 56.7 \\
Shivamogga & 956.3 & 299.0 & 31.3 & 641.2 & 222.1 & 34.6 & 191.7 & 105.1 & 54.8 \\
Zone & 927.3 & 172.1 & 18.6 & 589.0 & 176.7 & 56.9 & 194.2 & 109.6 & 65.1 \\
\hline
\end{tabular}

1. First calculate the average $=\frac{\mathrm{X}_{1}+\mathrm{X}_{2}+\ldots .+\mathrm{X}_{14}}{-\mathrm{H}}$

2. Start the cumulative sum at zero by setting $\mathrm{S} 0=0$.

3. Calculate the other cumulative sums by adding the difference between current value and the average to the previous sum, i.e., $\mathrm{S}_{\mathrm{i}}=\mathrm{S}_{\mathrm{i}-1}+\left(\mathrm{X}_{\mathrm{i}}-\right.$ for $\mathrm{i}=1$, $2 \ldots . .14$.

The sums of the variations between the values and their average are the total sums. All differences sum to zero, hence that the cumulative sum will always at zero (S14 =0). However, defining a CUSUM chart need some experience. Over the period, if the values appear to be higher than the overall average, then the majority of values added to the total will be positive and increase gradually. A CUSUM chart section with an upward slope shows a time when the values are generally higher than overall average. Section with downward slope, on the other hand denotes a span of time in which the values appear to be lower than overall average. A sudden shift in the average is showed by a sudden shift in the direction of the CUSUM. The average did not change during periods when the CUSUM chart followed a pretty straight path. The analysis detects different changes that occurred during the study period, with a confidence level associated with each change showing how optimistic the analysis is that the change occurred.
After choosing an estimator for the extent of the change, the bootstrap can be studied. A single bootstrap is accomplished by:

1. Generate a bootstrap sample of 14 units, denoted $\mathrm{X}^{0}{ }_{1}$, $\mathrm{X}_{2, \ldots,}^{0}, \mathrm{X}^{0}{ }_{14}$, by randomly re-ordering the original 14 values and is called sampling without replacement.

2. Based on the bootstrap sample, calculate the bootstrap CUSUM, denoted $\mathrm{S}_{0}^{0}{ }_{0} \mathrm{~S}^{0}{ }_{1}, \ldots, \mathrm{S}^{0}{ }_{14}$

3. Calculate the maximum, minimum and difference of the bootstrap CUSUM, denoted $\mathrm{S}^{0}{ }_{\min } \mathrm{S}_{\text {max }}^{0}$ and $\mathrm{S}^{0}{ }_{\text {diff }} \cdot$

4. Determine whether the bootstrap difference $\mathrm{S}_{\text {diff }}^{0}$ is less than the originaldifference $\mathrm{S}^{0}{ }_{\text {diff. }}$

The concept of bootstrapping is that, bootstrap samples reflect random reordering of data, simulating the behavior of CUSUM if there is no change. You can predict how much $S_{\text {diff }}$ will change if there is no change caused by running a large sets of bootstrap samples. Later compare this value to the $\mathrm{S}_{\text {diff }}$ value determined from the original order data to see whether it is consistent without change.

\section{RESULTS AND DISCUSSION}

\section{Rainfall statistics of the zone}

The mean annual rainfall of Southern transition zone is $927.3 \pm 172.1 \mathrm{~mm}$ with a coefficient of variation of 18.6 per cent. The taluk-wise information is furnished in 
Table 2: Taluk wise rainfall and rainy days trend in different seasons

\begin{tabular}{|c|c|c|c|c|c|c|}
\hline \multirow{2}{*}{ Taluk } & \multicolumn{3}{|c|}{ Rainfall } & \multicolumn{3}{|c|}{ Rainy days } \\
\hline & Annual & SWM & NEM & Annual & SWM & NEM \\
\hline Tarikere & $+\mathrm{ve}$ & $+\mathrm{ve}$ & -ve & $+\mathrm{ve}$ & $+\mathrm{ve}$ & + ve \\
\hline Channagiri & +ve & +ve & -ve & +ve & +ve & +ve \\
\hline Honnali & +ve & -ve & -ve & $*+\mathrm{ve}$ & $*+\mathrm{ve}$ & +ve \\
\hline Alur & -ve & *-ve & -ve & -ve & $*$-ve & +ve \\
\hline Arkalgudu & +ve & +ve & -ve & +ve & +ve & +ve \\
\hline Belur & -ve & -ve & -ve & +ve & -ve & +ve \\
\hline Hassan & $*+\mathrm{ve}$ & $+\mathrm{ve}$ & +ve & +ve & +ve & +ve \\
\hline Holenarsipura & +ve & +ve & -ve & $*+\mathrm{ve}$ & +ve & +ve \\
\hline H.D.Kote & +ve & +ve & -ve & $*+\mathrm{ve}$ & +ve & +ve \\
\hline Hunsur & +ve & -ve & -ve & $*+\mathrm{ve}$ & $*+\mathrm{ve}$ & +ve \\
\hline Periyapatna & -ve & -ve & +ve & +ve & +ve & +ve \\
\hline Bhadravathi & +ve & +ve & -ve & $*+\mathrm{ve}$ & $*+\mathrm{ve}$ & +ve \\
\hline Shikaripura & -ve & -ve & -ve & -ve & -ve & +ve \\
\hline Shivamogga & -ve & +ve & -ve & -ve & -ve & +ve \\
\hline Zone & +ve & -ve & -ve & $*+\mathrm{ve}$ & +ve & +ve \\
\hline
\end{tabular}

Note: ${ }^{*+v e}=$ Significant positive trend, *-ve = Significant negative trend, SWM: South West Monsoon, NEM: North East Monsoon

Table 3:Change point of rainfall for the study area

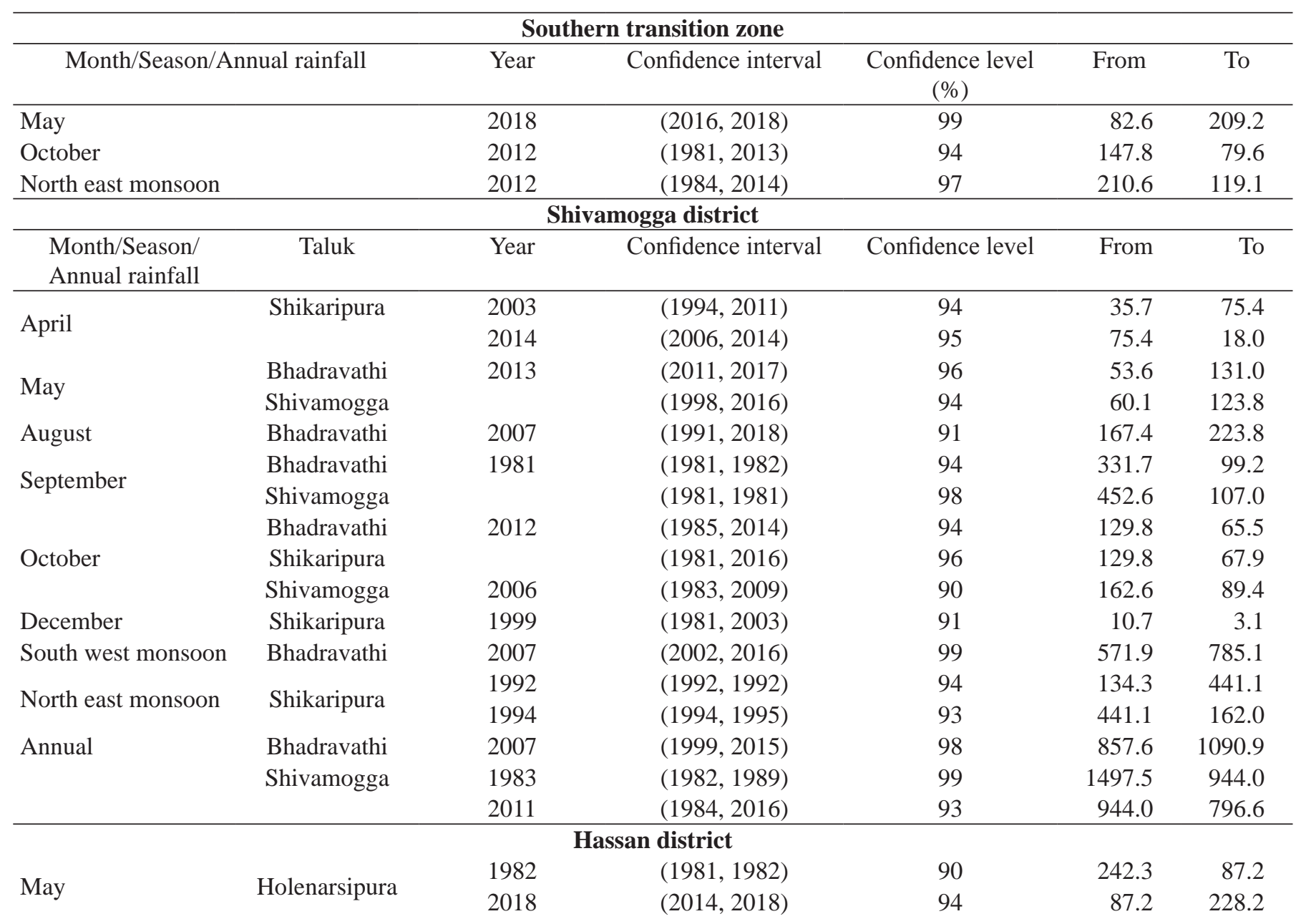




\begin{tabular}{|c|c|c|c|c|c|c|}
\hline \multirow{2}{*}{ July } & \multirow{2}{*}{ Alur } & 2000 & $(1981,2000)$ & 96 & 492.5 & 197.7 \\
\hline & & 2005 & $(2002,2018)$ & 94 & 197.7 & 396.3 \\
\hline \multirow{2}{*}{ August } & \multirow{2}{*}{ Holenarsipura } & 2000 & $(1990,2000)$ & 98 & 60.7 & 114.9 \\
\hline & & 2011 & $(2001,2014)$ & 98 & 114.9 & 68.8 \\
\hline \multirow[t]{2}{*}{ September } & Hassan & 1988 & $(1985,2011)$ & 95 & 151.9 & 99.5 \\
\hline & Alur & 2012 & $(1981,2013)$ & 95 & 187.2 & 70.6 \\
\hline \multirow{3}{*}{ October } & Belur & 2012 & $(1983,2013)$ & 100 & 161.7 & 73.2 \\
\hline & Hassan & 1987 & $(1986,2017)$ & 91 & 75.6 & 133.6 \\
\hline & Holenarsipura & 2006 & $(1981,2011)$ & 95 & 181.4 & 93.6 \\
\hline \multirow[t]{2}{*}{ South west monsoon } & Alur & 2010 & $(1983,2014)$ & 95 & 1245.6 & 870.4 \\
\hline & Alur & 2012 & $(1983,2014)$ & 96 & 259.8 & 120.2 \\
\hline \multirow[t]{3}{*}{ North east monsoon } & Arkalgudu & 2012 & $(1981,2012)$ & 98 & 209.4 & 120.9 \\
\hline & Belur & 2012 & $(1982,2014)$ & 98 & 232.6 & 123.0 \\
\hline & & 1991 & $(1989,1991)$ & 95 & 1119.9 & 1782.0 \\
\hline \multirow{3}{*}{ Annual } & Belur & 1993 & $(1992,2011)$ & 98 & 1782 & 1392.8 \\
\hline & & 2012 & $(2005,2016)$ & 100 & 1392.8 & 1049.3 \\
\hline & Hassan & 2005 & $(1998,2011)$ & 98 & 671.9 & 874.7 \\
\hline \multicolumn{7}{|c|}{ Mysore district } \\
\hline April & H.D.Kote & 1998 & $(1990,2018)$ & 92 & 60.0 & 100.0 \\
\hline \multirow{2}{*}{ June } & Hunsur & 1991 & $(1991,1991)$ & 93 & 70.9 & 224.4 \\
\hline & & 1993 & $(1993,1994)$ & 98 & 224.4 & 84.2 \\
\hline \multirow{2}{*}{$\begin{array}{c}\text { September } \\
\text { October }\end{array}$} & Periyapatna & 1997 & $(1981,2007)$ & 99 & 143.7 & 93.6 \\
\hline & & 2015 & $(1982,2015)$ & 97 & 151.4 & 49.1 \\
\hline \multirow{2}{*}{ South west monsoon } & Hunsur & 1991 & $(1983,2000)$ & 91 & 364.5 & 493.7 \\
\hline & & 2001 & $(1994,2005)$ & 94 & 493.7 & 352.9 \\
\hline \multirow{2}{*}{ North east monsoon } & Periyapatna & 1997 & $(1991,2007)$ & 98 & 183.6 & 276.4 \\
\hline & & 2012 & $(2007,2013)$ & 97 & 276.4 & 112.9 \\
\hline \multirow{2}{*}{ Annual } & Hunsur & 1997 & $(1989,1996)$ & 96 & 701.8 & 1010.2 \\
\hline & & 2001 & $(1995,2004)$ & 97 & 1010.2 & 723.3 \\
\hline \multicolumn{7}{|c|}{ Davanagere district } \\
\hline \multirow{2}{*}{ May } & Channagiri & 2013 & $(2006,2017)$ & 96 & 56.9 & 113.2 \\
\hline & Honnali & 2002 & $(1997,2017)$ & 99 & 38.7 & 92.0 \\
\hline October & Honnali & 2012 & $(1981,2013)$ & 98 & 132.7 & 69.4 \\
\hline North east monsoon & Honnali & 2011 & $(1981,2011)$ & 96 & 188.0 & 108.5 \\
\hline \multicolumn{7}{|c|}{ Chikkmagalore district } \\
\hline October & Tarikere & 2004 & $(1981,2011)$ & 92 & 155.1 & 100.1 \\
\hline
\end{tabular}

Table 1. During the period 1980-2018, the highest rainfall (2993.6 mm) was recorded at Alur taluk during 1994 while lowest rainfall (249.4 mm) was recorded in Hannali taluk during 1985. Annual rainfall is highly variable in Honnali taluk (32.6\%) followed by Shivamogga (31.3\%) and Holenarasipura taluks (28.0\%). Least variability in annual rainfall has been noticed in Periyapatna (19.2\%) and Tarikere taluks (21.6\%).

\section{Trend analysis}

Daily values of precipitation and rainy days have been converted into seasonal (Southwest monsoon and Northeast monsoon) and annual amounts. Linear trend was worked out and the significance of the trends was tested by Mann-Kendall test for annual rainfall (Table 2). Among the 14 taluks only Hassan taluk shows significant positive trend in annual rainfall and eight taluks (Tarikere, Channagiri, Honnali, Arkalgudu, Holenarsipura, H. D. Kote, Hunsur and Bhadravathi) have shown non-significant positive trend, remaining five taluks (Alur, Belur, Periyapatna, Shikaripura and Shimoga) have non-significant negative trend in annual rainfall. Similarly, Annual rainfall for the entire zone has shown non significant positive trend. Sevak et al. (2018) analyzed the long term rainfall of Sardarkrushinagar (1981-2017) and observed significant increase in annual rainfall at $13.9 \mathrm{~mm} /$ year over its normal rate of $704.1 \mathrm{~mm}$. The study also showed decadal change in rainfall trend by 
every alternate increasing and decreasing.

In case of number of annual rainy days, five taluks (Honnali, Holenarsipura, H. D. Kote, Hunsur and Bhadravathi) and zone as a whole have shown significant positive trend. Whereas, Tarikere, Channagiri, Arkalgudu, Belur, Hassan and Periyapatna showed non-significant positive trend and in remaining taluks (Alur, Shikaripura and Shivamogga) non-significant negative trend was observed for annual rainy days.

For the SW Monsoon rainy season, Alur taluk shows a significant negative trend and eight taluks (Tarikere, Channagiri, Arkalgudu, Hassan, Holenarsipura, H.D. Kote, Bhadravathi and Shivamogga) have shown non-significant positive trend. However, in five taluks (Honnali, Belur, Hunsur, Periyapatna and Shikaripura) and zone as a whole, Non-significant negative trend was observed. For the NEM season, 12 out of 14 taluks and zone as a whole have shown non-significant negative trend and the remaining two taluks (Hassan and Periyapatna) were shown non-significant positive trend in NEM rainfall.

In seasonal rainy days during SWM season, a significant positive trend was noticed in three taluks (Honnali, Hunsur and Bhadravathi) and only Alur taluk shows a significant negative trend. Seven taluks (Tarikere, Channagiri, Arkalgudu, Hassan, Holenarsipura, H. D. Kote and Periyapatna) and zone as a whole showed a non-significant positive trend. Whereas, non-significant negative trend was observed in Belur, Shikaripura and Shivamogga. During NEM season, all the taluks and zone as a whole noticed non-significant positive trend in rainy days.

\section{Change point detection}

For the monthly rainfall of the Southern transition zone, the change point occurs in May month during 2018 with the confidence level of 99 per cent. Before the existence of change, the mean monthly rainfall is about $82.6 \mathrm{~mm}$ and after change, it was $209.2 \mathrm{~mm}$. Similarly, the rainfall occurrence also changed during October and North east monsoon season (NEM) during 2012 with the confidence level of 94 and 97 per cent, respectively. The rainfall before change was 147.8 and $210.6 \mathrm{~mm}$ and after change it was 79.6 and $119.1 \mathrm{~mm}$ respectively in the southern transition zone. This clearly indicates the climate change in terms of shifts in the occurrence of rainfall. Hence, the May rainfall dependency may be used exclusively for land preparation rather than as a sowing opportunity (Table 3).

Taluk wise change point detection was estimated to know the rainfall pattern of southern transition zone (Table 3). In the Shivamogga district, the number of occurrences of change in rainfall distribution was higher in all three taluks. In Shikaripura, the April rainfall increased after the change point during 2003 (35.7 to $75.4 \mathrm{~mm}$ ) and decreased during 2014 (75.4 to $18.0 \mathrm{~mm}$ ). Similarly, in May and August the occurrence of rainfall was increased in Bhadravathi during 2013 and 2007 (53.6 to 131.0 and 167.4 to $223.8 \mathrm{~mm}$, respectively) and Shivamogga (60.1 to $123.8 \mathrm{~mm}$ ) during 2013 for May month. The decrease in rainfall was noticed after the change point in Bhadravathi (331.7 to $99.2 \mathrm{~mm}$ ) and Shivamogga (452.6 to $107.0 \mathrm{~mm}$ ) during 1981 in September month. In October month, all three taluks (2012 for Bhadravathi and Shikaripura and 2006 for Shivamogga taluk) and December month in Shikaripura also shown decreasing rainfall pattern. Seasonal and annual rainfall is concerned, in Bhadravathi southwest monsoon and annual rainfall was increased in 2007 (571.9 to 785.1 and 857.6 to $1090.9 \mathrm{~mm}$, respectively) and in Shivamogga, the change in annual rainfall was decreased during 1983 (1497.5 to $944.0 \mathrm{~mm}$ ) and 2011 (944.0 to $796.6 \mathrm{~mm}$ ). The northeast monsoon rainfall was increased during 1992 (134.3 to $441.1 \mathrm{~mm}$ ) and it was decreased during 1994 (441.1 to $162.0 \mathrm{~mm}$ ) in Shikaripura taluk. The increase in rainfall occurrence is always beneficial during summer months (April and May) for land preparation to sow the kharif crops. September and October months rainfall is crucial for crops to attain the flowering and maturity stage; reducing rainfall causes immature grains or declining yield. The sowing dates adjustment or selection of suitable short duration variety/hybrid can escape shortfall of moisture during the maturity stage. It is advisable to go for sowing of single crop due to reduced post-monsoon rainfall in the district's significant parts. Waghaye et al. (2018) analyzed the change point of annual rainfall of 23 stations of Andra Pradesh by using the MWP and CD test. The results reveals that quite variable change was found across the years but most probable change was noticed during 1953 as noticed over 5 stations.

In Hassan district, summer rainfall did not show 
any change in all the taluks except Holenarsipura. However, Holenarsipura noticed a decrease in rainfall during 1982 (242.3 to $87.2 \mathrm{~mm}$ ) and an increase during 2018 (87.2 to $228.2 \mathrm{~mm}$ ) in the May month. A decrease in July rainfall during 2000 (492.5 to $197.7 \mathrm{~mm}$ ) and increase $(197.7 \mathrm{~mm}$ to $396.3 \mathrm{~mm}$ ) was observed during 2005 in Alur taluk. Seasonal and monthly change in rainfall occurrence was higher in recent years, particularly Southwest, Northeast monsoon season, August, September and October months in all the taluks of Hassan district. This indicates that climate change negatively affects crop production due to irregular rainfall distribution even though there was a slight increase in annual rainfall in recent years. In Mysore district, the change of normal rainfall distribution was higher in Hunsur taluk. The increase and decrease of occurrence of rainfall change was noticed in June (1991 and 1993), South west monsoon season (1991 and 2001) and annual (1991 and 2001) and reduction of rainfall was observed in recent years. Similarly, in Periyapatna decease in rainfall was observed in September (1997), October (2015) and Northeast monsoon season (2012) it shows that shift in monthly rainfall distribution without affecting total annual rainfall. Summer rainfall is beneficial for land preparation for the sowing of kharif crops. The slight increase (60.0 to $100.0 \mathrm{~mm}$ ) in April rainfall was recorded in $\mathrm{H}$. D. Kote taluk.

The increase in rainfall was noticed in May month during 2013 and 2002 for Channagiri (56.9 to $113.2 \mathrm{~mm}$ ) and Honnali (38.7 to $92.0 \mathrm{~mm}$ ) taluks. In recent years in Honnali taluk, there was a decrease in October and Northeast monsoon rainfall that indicates go for sowing of short duration cultivars or adjust sowing time for normal crop production. In Tarikere taluk, the rainfall change occurred in October month during 2004. The normal monthly rainfall was $155.1 \mathrm{~mm}$ before the existence of change and it was $100.1 \mathrm{~mm}$ after the existence of change. Khapalova et al. (2013) applied the statistical methods for change point analysis of annual precipitation for northern, southern and tropical latitudes by using past 100 years data. According to the findings, there has been a significant shift in precipitation from southern to northern latitudes since 1944 . However, no change was noticed in the data of tropical latitudes. They concluded that, shift in data from southern to northern latitudes could not be due to gauge change which was introduced around 1950.

\section{CONCLUSIONS}

The results indicate that the annual rainfall had shown a rising trend, whereas the seasonal rainfall trend decreased. Still, it didn't negatively affect the total rainy days, both the seasons and annual. The variation in monthly rainfall during the Kharif season is the main cause of rainfall shift due to climate change. It often has adverse effects on crop production due to the irregular distribution of seasonal rainfall even there was a slight increase in annual rainfall in recent years. As a result, analysing the trend of a data set will assist water resource managers in reducing the impact of vulnerable disasters and to recommend changes in the cropping patterns.

\section{ACKNOWLEDGEMENT}

The authors are thankful for the Karnataka State Natural Disaster Monitoring Centre (KSNDMC), Bengaluru, for providing daily rainfall data of the study area. We are also grateful to the India Meteorological Department, New Delhi, for sanctioning of GKMS, Unit under this the study has been conducted.

Conflict of Interest Statement : The author(s)declare(s) that there is no conflict of interest.

Disclaimer : The contents, opinions, and views expressed in the research article published in the Journal of Agrometeorology are the views of the authors and do not necessarily reflect the views of the organizations they belong to.

Publisher's Note : The periodical remains neutral with regard to jurisdictional claims in published maps and institutional affiliations.

\section{REFERENCES}

Waghaye, A.M., Rajwade, Y. A., Randhe, R. D. and Nidhi Kumari (2018).Trend analysis and change point detection of rainfall of Andhra Pradesh and Telangana, India. J. Agrometeorol., 20 (2):160163.

Altava-Ortiz, V., Llasat, M.C., Ferrari, E., Atenciab, A. and Sirangelo, B.(2011). Monthly rainfall changes in Central and Western Mediterranean basins, at the end of the $20^{\text {th }}$ and beginning of the $21^{\text {st }}$ centuries. Int. J. Climatol., 31, 1943-1958.

Basseville, M. and Nikiforov, I. V. (1993). Detection of Abrupt Changes: Theory and application. 
Englewood Cliffs: Prentice Hall.

Khapalova E.A., Jandhyala V.K. and Fotopoulos S.B. (2013). Change-point analysis of annual meanprecipitation for northern, tropical and southernlatitudes of the globe in the past century. J. Environ. Stat., 4(3): 1-21.

Hu, Z., Zhou, Q., Chen, X., Qian, C., Wang, S. and Li, J. (2017). Variations and changes of annual precipitation in Central Asia over the last century. Int. J. Climatol., 37:157-170.

Hamed, K.H. and Rao, R. (1998).A modified MannKendall trend test for autocorrelated data. J. Hydrol., 204:182 196

Kendall, M.G. (1975) Rank Correlation Methods, 2nd edition. New York, NY: Hafner.

Kundu, S., Khare, D., Mondal, A. and Mishra,P.K.(2015). Analysis of spatial and temporal variation inrain fall trend of Madhya Pradesh India (1901-2011), Environ. Earth Sci., 73(12): 8197-8216.

Lunagaria, M. M., Pandey, V. and Patel, H. R. (2012). Climatic trends in Gujarat and its likely impact on different crops. J. Agrometeorol., 14(1): 4144

Mann, H.B. (1945). Non-parametric test against trend, Econometrica, 13:245-259.

Mckee, T.B., Doesken, N.J. and Kleist, J. (1993). The relationship of drought frequency and duration to time scales. In: Proceedings of the $8^{\text {th }}$ Conference on Applied Climatology, Anaheim, CA, USA p.179-184

Patakamuri, S.K., Muthiah, K. and Sridhar, V. (2020). Long-term homogeneity, trend, and changepoint analysis of rainfall in the arid district of Ananthapuram, Andhra Pradesh State, India. Water, 12(211):1-22.

Sen, P.K. (1968). Estimates of the regression coefficient based on Kendall's tau. J. Am. Stat. Assoc., 63:1379-1389.

Sevak, D., Patel, P.H., Chaudhary, M.G. and DESAI, A.I. (2018). Variability and trend analysis of rainfall for crop planning and management. Int. J. Agric. Sci., 10(6): 5554-5557.

Taylor Wayne (2000). Change-Point Analyzer 2.0 shareware program, Taylor Enterprises, Libertyville, Illinois.

Yang, X.L., Xu, L.R., Liu, K.K., Li, C.H., Hu, J. and Xia, X.H. (2012). Trends in temperature and precipitation in the Zhangweinan River Basin during the last 53 years. Procedia Environ. Sciences, 3:1966-1974.

Yue, S, and Hashino, M. (2003). Long term trends of annual and monthly precipitation in Japan. $J$ Am. Water Resource, 39(3):587-596.

Yue, S., Pilon, P. and Cavadias, G. (2002). Power of the Mann-Kendall and Spearman's rho tests for detecting monotonictrends in hydrological series. J. Hydrol., 259:254-27. 